\title{
Human Cells or Tissue Product
}

National Cancer Institute

\section{Source}

National Cancer Institute. Human Cells or Tissue Product. NCI Thesaurus. Code C101674.

A product that contains human cells or tissue. 